\title{
ニセコひらふ地区におけるリゾート開発と土砂災害リスク
}

\section{Resort Development and Landslide Disaster Risk in Niseko Hirafu Area}

\author{
塩㟝 大輔 $^{1} \cdot$ 橋本 雄一 $^{2}$ \\ Daisuke SHIOZAKI ${ }^{1}$ and Yuichi HASHIMOTO ${ }^{2}$
}

要旨

本研究はスキーリゾート開発が著しい北海道俱知安町のひらふ地区を対象とし, 開発の経緯を施設建設によって概観した 後, 各施設に関する土砂災害の危険性を空間的に検討することで, スキーリゾート開発と災害リスクとの関係を明らかにした。 そのために建築確認申請計画概要書から作成したデータベースで開発を年代別に分析し，当該地区の土砂災害リスクを国土 数值情報の災害関連情報とあわせて検討した。ひらふ地区の開発はバブル崩壊前後と 2000 年代後半に拡大した。特に海外か らの不動産投資が急増した 2000 年代後半からの開発では，スキー場に近接した施設建設の適地が不足したことにより，バブ ル期の開発に比べ，その開発範囲は河川沿いの急傾斜地にきわめて近い場所まで広がっていた。ここには高級コンドミニア ムなど比較的規模の大きい建築物が複数立地しており, 近年の観光施設集積地の縁辺部における大型開発が, 土砂災害の危 険性を高めていた。これらの結果から, 対象地域では好景気の時期に開発が進んでいることや, 開発の時期が新しいほど土 砂災害の危険性が高い場所で施設建設が行われていることが明らかになった。

キーワード：ニセコ，ひらふ，建築確認申請，土砂災害，リゾート開発

Key words : Niseko, Hirafu, construction confirmation application, landslide disasters, resort development

\section{I. はじめに}

高度経済成長期以降, 日本の積雪地域ではスキー リゾート開発が積極的に進められ（白坂，1986）, 北海道内でも有数の大型スキー場を中核とする観光 開発が行われた。その中で冬季の低温と大量の降雪 に恵まれた北海道の二セコ地域は，古くから観光開 発が行われ，2000 年以降には多くの外国人観光客 を集めるようになった（市岡ほか，2009）。

このニセコ地域の中でも俱知安町のひらふ地区 ${ }^{1)}$ は，温泉などがあったことから早い時期に開発され ており，スキーを目的とする外国人観光客がいち 早く集中したのもこの地区であった（小澤・池村, 2011)。また， 2000 年代から国内外の資本によりコ ンドミニアムなどが多数建設されたことで（遠藤, 2019）,この地区は 2006 年から 3 年連続で住宅地と しての地価上昇率全国 1 位となり，近年大きな注目 を集めている（高橋, 2020）。

日本のスキー観光に関する地理学的研究の動向は 呉羽 (2017) でまとめられており,その中ではスキー リゾート開発を研究する際に社会経済条件だけでな く自然条件にも注目する必要が指摘されている。こ の自然条件の中で，災害につながる可能性があるも のは特に重要となる。高橋ほか（1978）が，山腹斜 面における別荘地開発による土砂崩れの危険性を報
告しているように，スキー場周辺の傾斜地でもリ ゾート地区でも土砂贸害などが発生する可能性を考 慮すべきである。特に，ひらふ地区のような地区で は, 急速に進む観光開発により潜在的な災害の危険 性が増大している可能性があり，それを空間的な視 点で把握することが必要と思われる。

そこで本研究は, ひらふ地区を対象とし, 開発の 経緯を施設建設によって概観した後, 各施設に関す る土砂災害の危険性を空間的に検討することで，ス キーリゾート開発と災害リスクとの関係を明らかに する。

本研究では，まず俱知安町ひらふ地区における開 発を, 建築確認申請計画概要書から作成したデータ ベースを用いて明らかにする。次に, 当該地区の土 砂災害の危険性を国土数值情報の土砂災害危険箈所 と土砂災害警戒区域に関するデータにより検討す る。最後に，両者を重ね合わせ，開発と土砂災害り スクとの関係について考察する。

\section{II. 地域概観}

北海道虬田郡俱知安町と二セコ町からなるニセコ 地域ではスキーリゾート開発が進んでおり, ひらふ 地区, 花園地区, 東山地区, アンヌプリ地区がスキー リゾート地区の中核となっている（図 1)。

\footnotetext{
${ }^{1}$ 北海道大学大学院文学研究院 ·専門研究員 / Postdoctoral Researcher, Faculty of Humanities and Human Sciences, Hokkaido University, Japan

2 北海道大学大学院文学研究院 / Faculty of Humanities and Human Sciences, Hokkaido University, Japan
} 

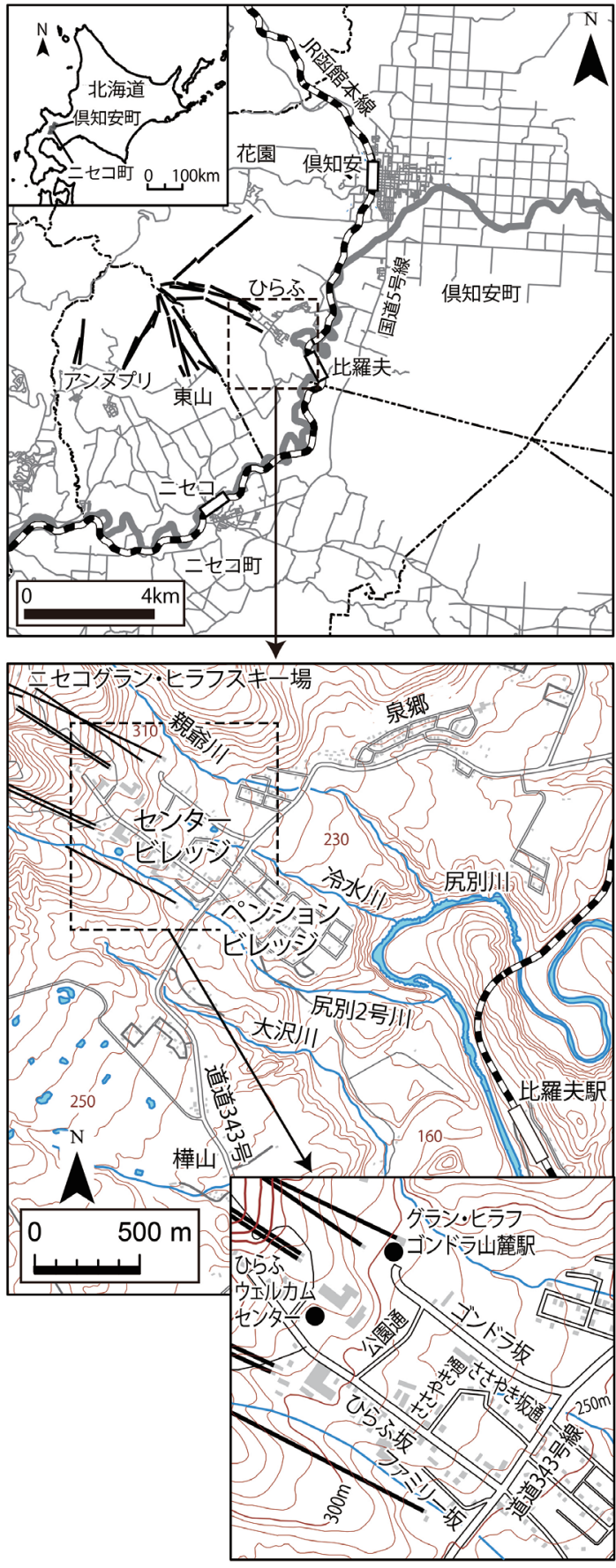

図 1 研究対象地域

俱知安町（2020）およびニセコ町（2020）から作 成した観光入り込み客数（延べ）の推移（1993 2018 年度）をみると（図 2), 2007 年から始まった 世界金融危機や東日本大震災（2011 年）の影響で 一時的に減少するものの，いずれの町の観光客も同 じレベルで増加している。外国人観光客宿泊客数(延 べ）の推移（2004～2018 年度）を見ると，観光入 り込久客数と同様に金融危機や震災の影響で一時的 に減少するものの，いずれの町でも急激な伸びを示 しており，期間中に俱知安町は 8.4 倍，二セコ町は 15.7 倍になっている。この様にニセコ地域は国際的

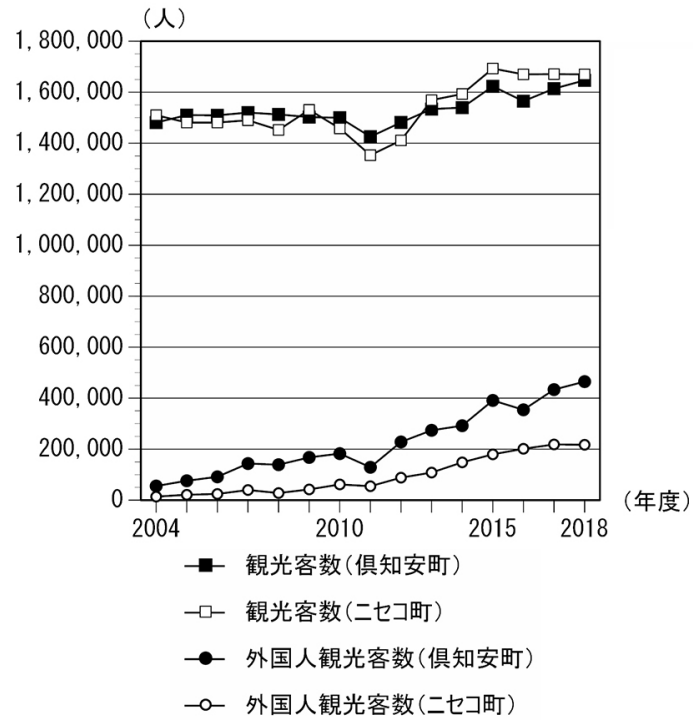

図 2 二セコ地域における観光客の推移 俱知安町およびニセコ町資料により作成。

な観光地として成長している。

\section{III. 建築確認申請からみたひらろ地区の開発}

本研究では, ひらふ地区の開発をみるため, 建築 確認申請をデータベース化して資料とする。建築確 認申請とは，建築物建築や大規模修繥を行う場合に は，工事着工前に建築物の設計や敷地配置などの計 画が建築基準法などに適合しているか検査を受ける ための申請である。この申請には建築物ごとの申請 年, 申請者所在地, 用途, 延床面積などが記されて いるため, 開発の詳細を把握できる。本研究では, $1975 \sim 2015$ 年に提出された 5,224 件の建築確認申 請に関する紙媒体の概要書を手入力してデータベー スを構築する 2 。

図 3 は, 1975 年から 2015 年までに申請された建 築確認申請件数を申請年代別に示している。1970 年代には，ひらふ地区センタービレッジのひらふス キー場に近い場所が観光地として開発され, 宿泊施 設などが申請されている（図 4)。1980 年代には道 道 343 号の南にあるひらふ地区ペンションビレッジ で民宿や個人用別荘地などの申請が行われている (図 5)。1980 年代後半にはバブル景気で投資が活発 になり，ひらふスキー場から離れた地域に開発が広 がっている。ひらふ地区ペンションビレッジでは, 尻別川や冷水川に近い急斜面付近での建築物が増加 している。用途はいずれも住宅であるが，建築主が 東京や札幌の開発会社であるため, 別荘として計画 された建築物と推察される。また, スキー場周辺部 から道道 343 号沿いに北東に進んだ親爺川手前に, 新たな建築物が申請されている。

1990 年代に入ると建築確認の申請地はさらに広 がり，企業により泉郷と呼ばれるリゾート・別荘地 開発が行われ，多くの申請が行われている。ここで 


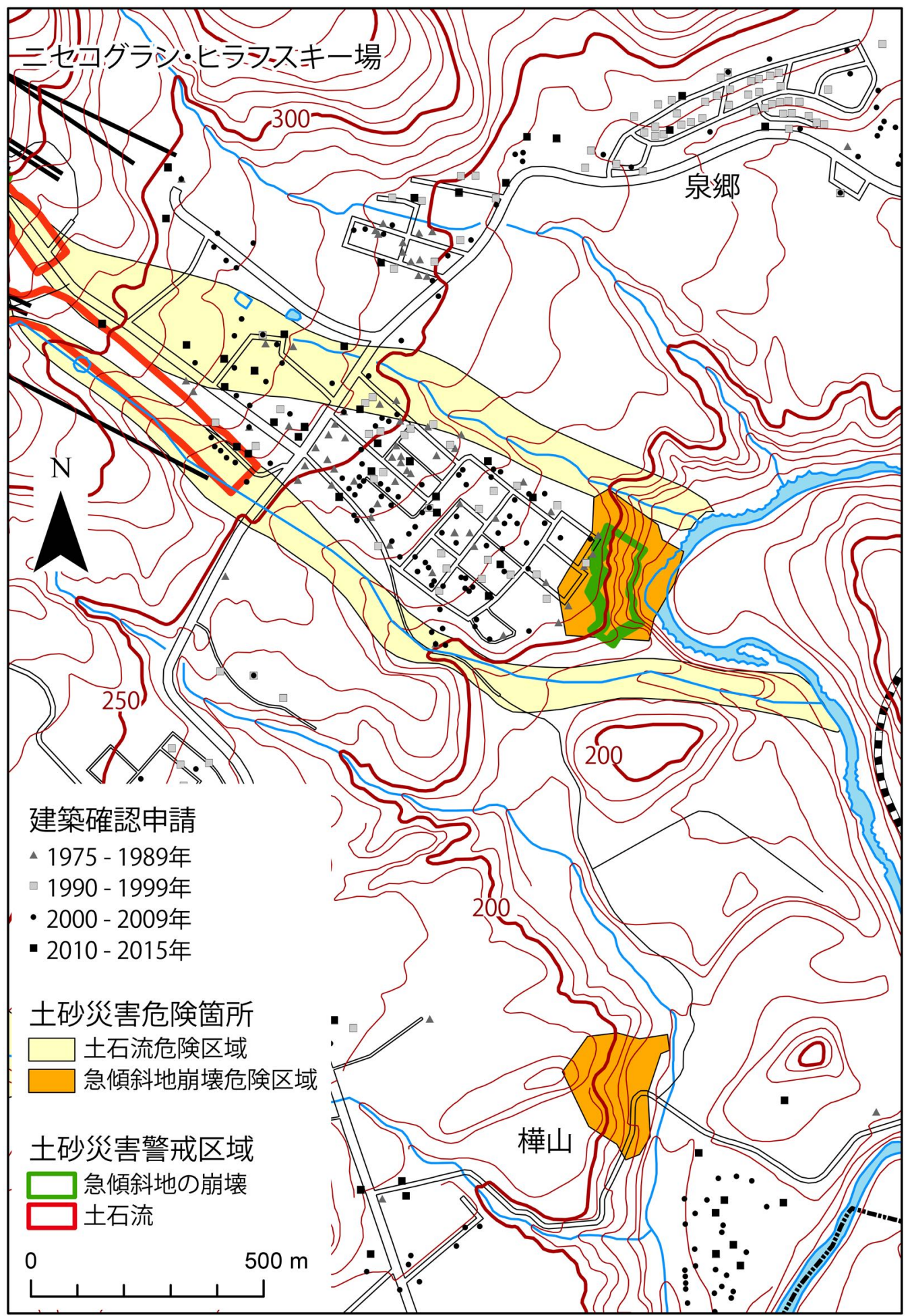

図３ひらふ地区に打ける建物立地と土砂災害リスク 建築確認申請㧍よび国土数值情報により作成。

は札幌市や道外の個人建築主による申請も確認で き，泉郷はバブル景気の時期に保養地として新たに 整備されたと考えられる。また 1990 年には親爺川 周辺でも，地形が急傾斜となる境界付近で申請があ り, 既存開発エリアも拡大している。

バブル景気の崩壊後には開発が停滞したが，2000
年代になると外国資本の参入によって申請件数は以 前よりも増加している。特に，ひらふ地区ペンショ ンビレッジに申請が集中し，尻別 2 号川の沿岸にあ る急傾斜地付近などで新たな開発が行われている (図 6)。また, ひらふ地区センタービレッジで開発 が活発化しており，それまで拡大傾向にあった開発 


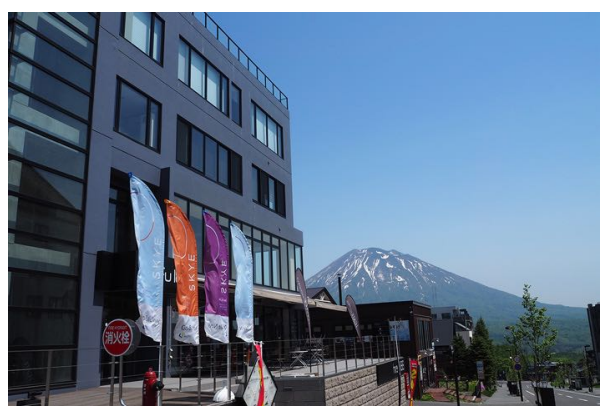

図4 ひらふ地区の様子

ひらふ坂より南西方向を撮影

(2016 年 5 月 22 日, 塩齐撮影)。

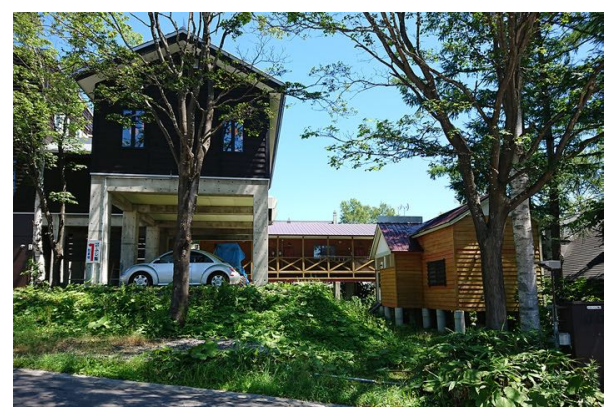

図 5 ひらふ地区ペンションビレッジの 傾斜地に立地する建築物 ようてい坂より東方向を撮影 (2018 年 7 月 28 日, 塩㠃撮影)。

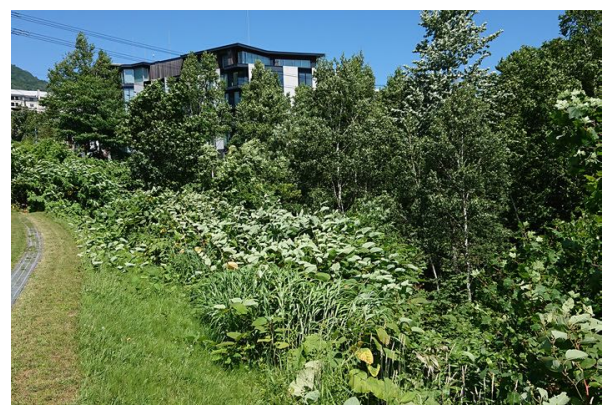

図 6 ひらふ地区ペンションビレッジ 尻別 2 号川沿いの様子

尻別 2 号川対岸から北東方向を撮影 (2018 年 7 月 28 日, 塩齐撮影)。

が、スキー場への近接性を重視したものにシフトし ている。

しかし，2007 年から始まった世界金融危機の影 響で，外国資本の投資意欲が減少したことで開発は 一時停滞した。それが 2010 年代になると, 経済の 回復とともに開発が活発化し，ひらふ地区の全域で 新たな申請がみられる。

\section{IV. ひらふ地区の土砂災害リスク}

ここでは，国土交通省の国土数值情報で公開され ている土砂災害危険箇所（2010 年度作成）と土砂 災害警戒区域（2019 年度作成）を用いて，ひらふ
地区における土砂災害リスクを分析する。

ひらふ地区には，複数の土砂災害危険箇所および 土砂災害警戒区域が分布する。土砂焱害危険箇所は 地形図, 空撮図, 都市計画図などを用いて土砂災害 の発生する可能性を判断した範囲である ${ }^{3)}$ 。

図 3 には土砂災害危険箇所が 4 箇所記載されてお り，うち 2 箇所は土石流危険区域 ${ }^{4)}$ に区分される。 その他の 2 箇所は急傾斜地崩壊危険区域 ${ }^{5}$ であり, ひらふ地区ペンションビレッジの尻別川沿いは 5 戸 以上の建物などが被災する恐れのあるI 種に，樺山 は 1 種よりは想定は小さいものの被棪の恐れがある III種 ${ }^{6)}$ に指定されている。

この土砂災害危険箇所は机上での災害想定である のに対し, 土砂災害警戒区域は現地調査により災害 発生の可能性が判断され, 土砂災害防止法に基づい て指定される。この土砂災害警戒区域は, 国土数值 情報では 3 箇所で確認できる。スキー場周辺エリア に存在する土石流危険区域内の 2 箇所が土砂災害警 戒区域（土石流）となっており，これは2016年度 に指定されたものである。他にはひらふ地区ペン ションビレッジの尻別川付近が土砂災害警戒区域 (急傾斜地の崩壊) に指定されている。

\section{V. ひらふ地区における開発と災害リスク}

\section{1. 建築確認申請と土砂災害危険䇢所}

土砂災害危険箇所の範囲内では，複数の建築物の 確認申請が行われている。土石流危険区域内の建築 物を年代別にみると，1970 年代後半および 1980 年 代前半にはスキー場付近で 10 件の建築物が申請さ れている。1980 年代後半になると, バブル経済期 の好況を背景に, スキー場周辺での開発が進み, 危 険個所内に 5 年間で 16 件の建築確認が申請される。 この時期には，泉郷や樺山を除いたひらふスキー場 周辺だけで 65 件の建築確認が申請されており，そ の 2 割以上が危険区域で申請されている。また，ス キー場から離れた場所にあり，勾配が大きな尻別川 付近に, 4 件の建築確認が申請されており, これは 1980 年代前半までにはみられない新たな傾向であ る。この時期にはひらふ地区の開発エリアが，尻別 2 号川や大沢川沿いの急斜面にまで広がっている。

バブル崩壊後の 1990 年代には申請数が減少する ものの，2000 年代に入ると再びひらふ地区におけ る開発が活発になる。2000 年代前半は 10 件の申請 があり, 全てが住宅や宿泊施設, 飲食店などのリゾー 卜開発関連と考えられる建築物である。なお， 2004 年には初めて外国人により建築確認申請が出される が, その建築物も土砂災害危険箇所の範囲内にある。 2000 年代後半になると, 23 件の建築確認申請が土 砂災害危険箇所内に申請され，外国人建築主による 開発が危険区域内において拡大している（図 7）。

2010 年代に入ると, 危険地域に 17 件の建築確認 が申請されている。2000 年代後半には個人建築主 による申請が多くみられるのに対し，2010 年代に 


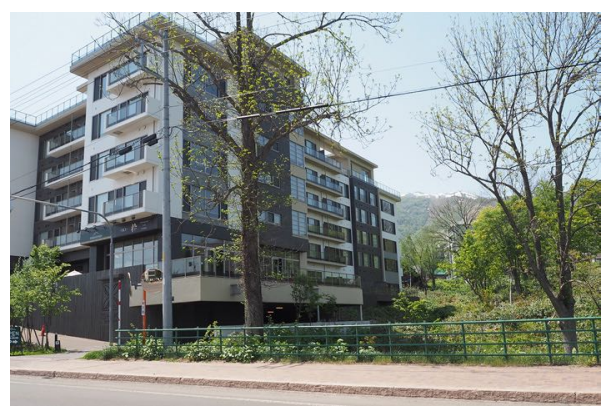

図 7 冷水川斜面沿いに立地する建物 道道 343 号から北西方向を撮影 (2016 年 5 月 22 日, 塩崎撮影)。

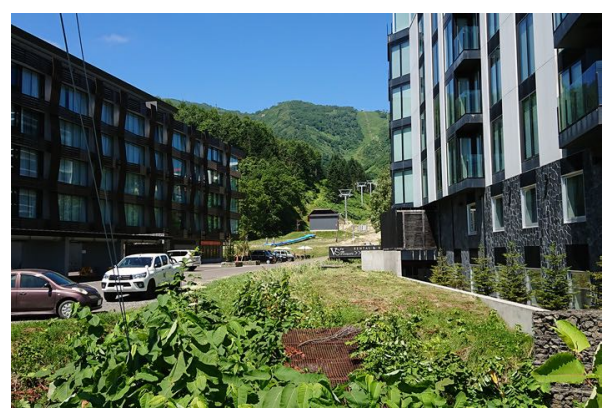

図 8 土砂災害警戒区域内に立地する建物 道道 343 号から尻別 2 号川に向けて北方向を撮影 (2018 年 7 月 28 日, 塩崎撮影)。

企業による申請が大部分を占める。

\section{2. 建築確認申請と土砂災害警戒区域}

2016 年度に指定された土砂災害警戒区域内にお ける建築確認申請をみると, 1975 年以降に申請さ れたものは 10 件である。そのうち 1990 年代までに 申請されたのは, 1984 年の宿泊施設と 1994 年のレ ンタルコテージの 2 件のみである。

2000 年代以降に 8 件が申請されており，2002 年 には宿泊用途が 2 件申請されている。これらの建築 面積は $299.82 \mathrm{~m}^{2}, 295.1 \mathrm{~m}^{2}$ と, 1990 年代以前に比 べては大きい。2003 年には建築面積 $209.7 \mathrm{~m}^{2}$ の住 宅兼宿泊用途建築物が 1 件，2004 年と 2005 年には 建築面積が $161.95 \mathrm{~m}^{2}$ と $238.58 \mathrm{~m}^{2}$ の住宅用途建築 物が 2 件申請されている。

2007 年と 2008 年には 7 階建ての大規模な高級 コンドミニアムが申請され， 1 件は建築面積 715.79 $\mathrm{m}^{2}$, 延床面積が $4,734.8 \mathrm{~m}^{2}$ であり，もう 1 件は建 築面積が $703.56 \mathrm{~m}^{2}$ ， 延床面積が 4,645.84 $\mathrm{m}^{2}$ であ る。これらが完成したことで，ひらふ地区では大人 数の宿泊客を受け入れられるようになったが7)，土 砂災害警戒区域内であるため土砂災害リスクへの対 応が必要となっている（図 8)。先にも述べたよう に，土砂災害区域の指定は，土砂流入の可能性が考 えられる区域において，人的あるいは建物被害が発 生する場合にのみ指定される。つまり，ひらふ地区
は2 2000 年代以降に開発が拡大し, 河川流域に近い 急傾斜地近くまで比較的規模が大きい建築物が立地 するようになったことで，土砂災害警戒区域に指定 されるなど災害リスクが顕在化したといえる。

\section{VI. おわりに}

本研究では, 俱知安町のひらふ地区に扔いて, 好 景気の時期における開発により, 土砂災害の危険性 が高い範囲で開発が進んでいることが明らかになっ た。建築確認申請をみると, 1970 年代後半は開発 がひらふ地区センタービレッジに限定されていた ものの, 1980 年代後半からのバブル経済の時期と, 2000 年代中頃からの好況期に多数の施設が建設さ れていた。1980 年代はペンションビレッジや泉郷 などスキー場から開発範囲が広がり，それが 2000 年代になると、ひらふ地区全域で開発が拡大した。 さらに 2000 年代以降は, 1980 年代に比べてスキー 場周辺で施設の大型化が進み, その建設範囲は河川 沿いの急傾斜地近くまで広がった。これは, 2000 年代以降に, ひらふ地区で最も開発が古いセンター ビレッジ地区で再開発が進んだことや，スキー場に 近接した場所に海外からの投資が集中したことによ り，施設建設の適地が不足したことによると考えら れる。このように，新しい年代の開発ほど自然災害 の危険性が大きい場所で施設建設が行われているこ とが明らかになった。

ひらふ地区のグランヒラフスキー場周辺は尻別川 と 2 本の尻別川支流に挟まれた土地であり，スキー 場で土砂災害が発生した場合, 尻別 2 号川に沿って 土砂が流れ出す危険性がある。その場合には, ファ ミリー坂周辺には高級コンドミニアムなど比較的規 模の大きい建築物が複数立地している地区で人的被 害や経済的被害が出る可能性がある。

土砂災害警戒区域に指定された場合は，住民への 周知や対策を講じることが求められる。ひらふ地区 の不動産物件は海外の個人や企業の所有物であり, 物件の利用者には土砂災害のリスクや対策が周知さ れていない可能性がある。そのため滞在時に災害が 発生した場合は大きな混乱を招く恐れがある。現在, 俱知安町や後志総合振興局では八ザードマップなど を多言語化し公開するなど対策を講じているが，い かに災害発生時に一時滞在者の状況を把握し, 情報 を伝達するのかといった対策まで踏み込む必要があ る。

\section{謝 辞}

本研究を進めるにあたり, 北海道後志振興局の職員の皆様 に大変貴重な情報をご提供頂きました。ここに記して厚く御 礼申し上げます,な㧍, 本研究は, 文部科学省「災害の軽減 に貢献するための地震火山観測研究計画 (第二次)」および JSPS 科研費 19K01166「千島海溝地震による津波の避難行動 モデル化と情報統合システム構築」における成果の一部であ る。 


\section{注}

1)「ひらふ」と呼ばれる地区は，主に俱知安町字山田および 字樺山からなる地区である。な技俱知安町字比羅夫は羊蹄 山側に位置しており，尻別川を挟んでいるためリゾート開 発の影響は小さい地区となる。

2) 建築確認申請の対象となる建築物は, (1) 特殊建築物で床 面積の合計が $100 \mathrm{~m}^{2}$ を越えるもの，(2) 木造で階数が 3 以 上もしくは延べ面積が $500 \mathrm{~m}^{2}$ を越えるもの，あるいは高 さ $13 \mathrm{~m}$, 軒高 $9 \mathrm{~m}$ を越えるもの，(3) 木造以外で階数が 2 以上のもの，もしくは延べ面積が $200 \mathrm{~m}^{2}$ を越えるもの，(4) これら以外で都市計画区域もしくは準都市計画区域内のも のである。なお, 対象とする俱知安町は 2008 年に, 二セ コ町は 2009 年に新たな準都市計画区域の指定を行ってお り，その前後で対象となる建築物の基準が異なる。

3) ニセコ地域の危険箇所は北海道庁後志総合振興局小樽建設 管理部によって調査されたものである。

4) 土石流が発生した場合に人家や公共施設に被害が予想され る危険区域にあり，勾配が 3 度以上の渓流に指定されてい る。ひらふ地区の主要開発地は河川の流域に挟まれており, いずれもI 種（土石流・がけ崩れの発生の危険性がありな おかつ 5 戸以上の人家，もしくは公共施設や災害弱者施設 が 1 施設以上に被害を生じる恐れがある渓流・がけ地）に 指定されている。

5) 傾斜度 $30^{\circ}$ かつ高さ $5 \mathrm{~m}$ 以上の急傾斜地で人家等に被害を 与えるおそれのある箇所。

6) 家等の被害はないが, 将来的に住宅開発により保全対象が できる可能性の高い地域。

7) ニセコに立地する高級コンドミニアムの性格上，これらは 外国人観光客がターゲットの宿泊施設と予想される。実際 に，これらの建築主は外国人建築主であり，施設のホーム ページをみても多言語による解説や，外国人スタッフによ るスキーレッスンなどが強調されている。

\section{文献}

市岡浩子 · 河本光弘・成澤義親（2009）：二セコ地域へのイ ンバウンドの動向と展望についての考察. 都市学研究, 46 19-26.

遠藤公正 (2019) : 注目のリゾート地「ニセコ地区」開発の過去・ 現在. そして未来. 北洋銀行ほくよう調査レポート, 276 , 6-12.

小澤丈夫・池村菜々（2011）：北海道に扔けるスキー場に隣 接する地域の形成過程と空間構成 ニセコひらふ地区を事 例として. 日本建築学会計画系論文集, 76 (662), 843-850. 俱知安町 (2020) : 『俱知安町の統計 2020 年版』俱知安町. 呉羽正昭（2017）：『スキーリゾートの発展プロセス：日本と オーストリアの比較研究』二宮書店.

白坂 蕃（1986）：『スキーと山地集落』明玄書房．

高橋克英（2020）:『なぜニセコだけが世界リゾートになった のか「地方創生」「観光立国」の無残な結末』講談社.

高橋伸夫 ·藤沢紘一 一小林浩二 ·西脇保幸 (1978)：伊豆 湊地区に打ける沿岸集落の観光地化. 人文地理学研究, 2 , 69-93.

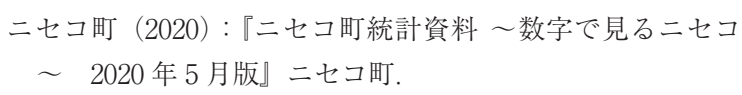

(2021 年 4 月 7 日受理 